\title{
VOZES DE OUTRORA: A POESIA DE AUTORIA FEMININA NO BRASIL DO ENTRESSÉCULO (XIX/XX)
}

\author{
Marcelo Medeiros da Silva ${ }^{1}$ \\ Josivânia da Cruz Vilela ${ }^{2}$
}

RESUMO: A partir da análise de alguns poemas produzidos por mulheres do século XIX, o artigo propõe-se a refletir acerca da poesia brasileira de autoria feminina no Brasil, evidenciando não só os temas de que trataram algumas poetisas, em especial, Gilka Machado, Pórcia C. Melo, Francisca Júlia, Narcisa Amália, Júlia Cortines, Maria Amélia Queiroz, mas, sobretudo, como elas dialogaram ou colidiram com os preceitos das estéticas literárias oitocentistas.

Palavras-chave: Poesia oitocentista. Escrita feminina. Crítica feminista.

\section{Introdução}

Durante muitos anos, as mulheres brasileiras viveram (e talvez ainda vivam) sob o prisma de um olhar machista e patriarcal que as trancafiou em um mundo obscuro e sem muitas expectativas de liberdade para exporem seus desejos e imaginações (TELES, 1987). De acordo com Paixão (1991), esse era o cenário em que muitas das poetisas do século XIX produziram suas obras, época em que a escrita de autoria feminina dificilmente resplandecia para além de um quarto escuro, já que ao homem "cabia o domínio dos espaços sociais, culturais e intelectuais da vida pública e, às mulheres, a limitação aos aposentos privados e a responsabilidade sobre os cuidados com o lar e a família" (PEREIRA, 2009, p. 33). Mesmo assim, inúmeras foram as escritoras que se valeram da escrita como um ato de rebeldia em prol da própria existência e nos legaram um conjunto vasto de textos literários ou não que revelam a participação das mulheres para além do espaço privado do lar e que nos auxiliam a pensar na contribuição feminina à cultura de nosso país. Apesar da profusão de gêneros escritos por mulheres no século XIX, a poesia despontou como o gênero mais cultuado e, no dizer de Ferreira (1991), configurou-se como o lugar da fala possível:

[...] escrever poemas era, na maioria dos casos, a única ocasião possível de dizer a si própria, de se construir sujeito de uma fala. É o espaço onde cada uma se oculta ou se desvela, onde uma voz antes silenciosa e silenciada pode dizer $\mathrm{Eu}$, minha, meu, falando da impressão que lhe causa uma paisagem, uma flor, o homem amado. É o espaço onde um Eu se vê escrevendo, consciente de que sua voz ultrapassará os muros espessos do lar, alcançará outras pessoas. Uma fala subversiva.

[...] Esta palavra feminina é uma afirmação, a recusa da solidão, a instituição de um diálogo com o interlocutor possível. Ela diz um ser feminino em seu desejo de ver claro em si, de se relacionar com o próximo. A poesia é ao mesmo tempo espaço de evasão, de fuga a um real esmagador e lugar onde outro real é criado, e um Eu se estrutura: no desvelar os atributos ao seu ser, no descrever um fazer feminino, na

\footnotetext{
${ }^{1}$ Doutor em Letras pela Universidade Federal da Paraíba e docente da Universidade Estadual da Paraíba, onde atua no Programa de Pós-Graduação em Formação de Professores e na licenciatura em Letras, ministrando disciplinas na área de Literatura e coordenando o subprojeto de Letras vinculado ao Programa Interinstitucional de Bolsas de Iniciação à Docência. E-mail: marcelomedeiros_silva@yahoo.com.br

${ }^{2}$ Graduanda em Letras - Língua Espanhola - pela Universidade Estadual da Paraíba, Campus VI. Atua nos seguintes temas: poesia oitocentista; escrita de autoria feminina; critica feminista; narrativa latino-americana contemporânea. Integrante do Grupo de Estudos de Literatura e Crítica Contemporâneas (UEPB/CNPq). Bolsista do Programa Institucional de Bolsas de Iniciação Científica (PIBIC/ UEPB/CNPq). E-mail: josivaniacruzvilela@gmail.com
}

IPOTESI, JUIZ DE FORA, v.23, n.1, p. 98-112, jan./jun. 2019 
entrega do pensamento do sujeito lírico diante do Outro, seja ele o amado, uma amiga, o Pai, a Mãe, Deus, o Leitor (FERREIRA, 1991, p. 13-14).

Não foi, portanto, fácil para as mulheres-escritoras de tempos pretéritos começarem a se expressar em meio a uma sociedade extremamente preconceituosa. Em virtude de o campo literário ser dominado por homens (na maioria dos casos, brancos, heterossexuais e da elite), a produção literária de autoria feminina se configurou, em meio a um cenário de opressão e interdição, como uma transgressão. Por isso, muitos dos escritos produzidos por mulheres foram bastante criticados, o que levou as poetisas, em um primeiro momento, a abandonarem esses escritos e deles não restou nada ou, em uma estratégia bastante sutil, a abordarem temas que a sociedade lhes prescrevia, ainda que o fizessem a partir de "uma fala e de uma temática diferentes da do homem" (PAIXÃO, 1991, p. 174).

Podemos constatar, portanto, o quanto era contraditória para as mulheres a sua condição social no século XIX: era esperado que elas seguissem com o destino, socialmente, já predeterminado, isto é, casarem-se, tornarem-se esposas prestimosas e mães de família, mas tal imposição impulsionou muitas delas a irem de encontro a esse destino e a traçarem para si outros enredos. As que transgrediram as normas sociais assumiram o risco e o preço dessa transgressão e foram difamadas ou impelidas ao esquecimento, como, por exemplo, aconteceu com as poetisas Narcisa Amália, que após se separar do marido, Francisco Cleto, viu-se obrigada a sair de Resende, cidade onde morava, pois, provavelmente, o ex-marido com ciúme começou a difamá-la, tendo, aliás, a acusado de não ser a autora dos poemas que compunham o livro intitulado de Nebulosas, escrito pela poetisa; e Gilka Machado, chamada por Machado de Assis (1978, p. IX, apud DIAS, 2011, p. 03) de "matrona imoral", devido ao fato de a poetisa tematizar em suas obras sensações, imaginações, desejos e sonhos considerados, aos olhos dos moralistas de plantão, impróprios à dicção feminina em nossa literatura.

É a partir de reflexões sobre o ser mulher e sobre o que isso acarreta em uma sociedade extremamente machista, e da busca do autoconhecimento, que as poetisas do século XIX começaram a engendrar caminhos antes não percorridos e considerados tabus para a época. Um deles é expressão do desejo que começa a ser tema de vários poemas. Como escrever era uma transgressão, falar sobre o desejo, as aspirações da carne e da alma era mais transgressor ainda. Por isso, de acordo com Paixão (1991), as poetisas se valeram de estratégias retóricas para expressar, de forma sutil, esse desejo. Dentre essas estratégias, uma delas foi o recurso a metáforas florais por meio das quais as mulheres puderam falar de amor, dor, desejo, erotismo sem, necessariamente, romper com os códigos comportamentais impostos ao sexo feminino. Ou seja, considerando-se que amor e flor eram temáticas previamente determinadas, as poetisas se valeram de tais temáticas, vistas como amenas, para exporem seus desejos mais íntimos, reprimidos e secretos: "pela sua textura macia, pelo perfume que evoca sensações, [as metáforas florais] são a brecha por onde escapa ao cerceamento social apresentando uma eroticidade camuflada" (PAIXÃO, 1991, p. 73).

A presença da natureza em poemas escritos por mulheres do século XIX não só aponta para a preponderância e o gosto feminino pelo verde, mas, ao mesmo tempo, em nossa percepção crítica, metaforiza a resistência feminina que, mesmo diante das coerções sociais, brotava com mais vitalidade em cada verso escrito, em cada livro publicado. Além disso, como reitera Paixão (1991), a presença da natureza era uma válvula de escape por meio da qual as poetisas expressavam seu desejo pelo outro e pelo mundo. Todavia, é um equívoco pensar que as poetisas de outrora falaram apenas de amor e de flores. Na esteira de Siqueira e Dantas (1991), mostraremos na secção a seguir, a partir de poemas escritos por Gilka Machado ${ }^{1}$ (18931980), Pórcia C. Melo ${ }^{2}$ (XIX-?), Francisca Júlia ${ }^{3}$ (1871-1920), Narcisa Amália ${ }^{4}$ (1852-1924), Júlia Cortines ${ }^{5}$ (1868-1953), Maria Amélia Queiroz ${ }^{6}$ (1918-2001), que a poesia de autoria feminina no Brasil oitocentista apresentou uma gama de temas que eram perpassados por

IPOTESI, JUIZ DE FORA, v.23, n.1, p. 98-112, jan./jun. 2019 
questões políticas, religiosas, mas que também se voltavam para a expressão de reflexões sobre o tempo, a infância, a vida com suas alegrias e tristezas. Ademais, vamos encontrar muitos poemas metalinguísticos que revelam a percepção das poetisas acerca da própria poesia e do lugar social da mulher escritora.

\section{Flores do desejo: mulher e escrita no entresséculo XIX-XX}

Gilka Machado foi uma das principais poetisas que cravou em suas obras a temática do desejo enquanto expressão erótica da existência. Ela "introduz na sua fala a proposta desse deleite sensual fazendo do olfato, da audição e, sobretudo, do tato a maneira de cindir o seu próprio Eu, identificando-se inteira no seu desejo do outro" (PAIXÃO, 1991, p. 136). No conjunto de sua obra que, sob a organização de Jamyle Rkain, foi recentemente reeditada pelo Selo Demônio Negro, a poetisa, mais que objeto de desejo, se mostra como sujeito que deseja; de tal forma que alguns estudiosos chegaram a confundi-la com o eu lírico dos poemas que escreveu. Acerca dessa confusão entre vida e obra, Massaud Moisés (1984) afirmou o seguinte: "a franqueza rude da poetisa, que tantos desgostos lhe causou, correspondia a vivências reais ou imaginárias? Na verdade, é questão ociosa: à semelhança dos poetas de Orfeu, a autora de Mulher Nua praticava a sinceridade fingida ou o fingimento sincero, fingindo "que é dor/ A dor que deveras sente” (MASSAUD MOISÉS, 1984, p. 257, apud. DIAS, 2011, p. 03). Se a poesia de Gilka Machado era fruto da própria vida ou performatizava certo fingimento poético, isso não deveria ter sido a régua que avaliou autora e obra e que as legou ao esquecimento. Todavia, podemos afirmar que, seja falando do amor, da mulher, da vida, dos sonhos ou mesmo do desejo, como veremos a seguir no poema Volúpia, a poesia para Gilka Machado era "tão indispensável à existência como a água, o ar, a luz, a crença, o pão e o amor" (NOVALES COELHO, 1978, p. XI, apud. DIAS, 2011, p. 06).

"Volúpia"

\footnotetext{
Tenho-te, do meu sangue alongada nos veios, À tua sensação me alheio a todo o ambiente; Os meus versos estão completamente cheios Do teu veneno forte, invencível e fluente.

Por te trazer em mim, adquiri-os, tomei-os, O teu modo sutil, o teu gesto indolente. Por te trazer em mim moldei-me aos teus coleios, Minha íntima, nervosa e rúbida serpente.

Teu veneno letal torna-me os olhos baixos, $\mathrm{E}$ a alma pura que trago e que te repudia, Inutilmente anseia esquivar-se aos teus laços.

Teu veneno letal torna-me o corpo langue, Numa circulação longa, lenta, macia, A subir e a descer, no curso do meu sangue.
} (MACHADO, 2017, p. 153)

Em consonância com a produção de outras poetisas oitocentistas, Gilka Machado fala do desejo que não lhe é permitido expressar abertamente. Por isso, em muitos de seus poemas, camufla esse desejo a partir de metáforas. O título do soneto acima sinaliza para o prazer sexual que se espraia ao longo de cada verso e que tem na imagem da serpente a sua maior expressão. A volúpia de que trata o poema se afigura como uma força atávica que faz parte da natureza 
feminina e da qual as mulheres não podem se esquivar, ainda que tentem. Sendo como a serpente, o desejo encanta, seduz e, por mais que se procure resistir, acaba-se inebriado por ele.

Nesse sentido, ao expressar a relação desejo e resistência, o eu lírico revela consciência de estar transitando por campos considerados impróprios ao sexo feminino - corpo, sensualidade e desejo. Por isso, procura negar esse desejo, mas o faz a partir de um discurso que se revela bastante sensual, o que corrobora ainda mais o desejo que, a princípio, se quer negar. No final dessa luta, o que temos é um corpo exangue em virtude dos efeitos que lhe causou o veneno forte e letal. A impressão de leitura que fica é que, uma vez acontecida a irrupção do desejo, não há como aplacá-lo.

Embora fosse uma das temáticas prediletas entre os homens, o amor como temário da produção literária de autoria feminina era tido como mais uma transgressão, uma vez que, dentro das normas de pureza e recato, as mulheres não poderiam expor suas emoções. Isso, no entanto, não impediu que muitas das poetisas escrevessem poemas amorosos, como veremos a seguir na poesia Que me pedes, de D. Pórcia C. Melo:

\section{"Que me pedes" \\ Não sou linda flor \\ De aroma sutil \\ De cores mimosas \\ Que brilha entre mil.

\begin{abstract}
Não sou avesinha
De canto amoroso,

Nem rio que passa

Nem doce brisa

Brincando ligeira

Falando de amores.
\end{abstract} \\ No bosque saudoso. \\ $\mathrm{Na}$ selva entre flores}

Não sou da noute

A estrela brilhante,

Nem sou da fortuna

O tempo ofuscante.

Não sou melodia

De órgão sagrado

Nem fada nem anjo

Por Deus bafejado.

Eu sou infeliz!

Que tenho pra dar?

Só meu coração

Constante em te amar.

(MELO, 1890, p. 08, apud SIQUEIRA; DANTAS, 1991, p. 141)

Muitas vezes, a partir de um tom melancólico, a temática amorosa nos textos de autoria feminina denunciava a ausência do outro e a busca incessante por complementaridade. No poema acima, a autora retoma um conjunto de imagens românticas para falar de sua solidão e infelicidade amorosa. Todavia, a poetisa pauta seu discurso em negações ("Não sou linda flor/ Não sou avesinha/ Nem rio/ Nem doce brisa/ Nem estrela/ Nem sou da fortuna/ Não sou melodia/ Nem fada nem anjo), desconstruindo todo um estereótipo da mulher oitocentista, a qual era tachada por muitos críticos de frágil e angelical. Qualificar as mulheres a partir de 
termos que reiteram certos estereótipos era estratégias masculinas, a partir das quais se estabelecia um perfil feminino pautado no endeusamento da mulher que teria de, por essa razão, ser doce, meiga, obediente, submissa e, principalmente, em seus escritos, falar de temas amenos. Em outras palavras, o que se queria era demarcar o lugar da mulher-escritora (aliás, de todas as mulheres) na sociedade brasileira no entresséculos (XIX/XX) e igualmente definir o que elas poderiam ou não escrever.

No caso do poema de Pórcia de Melo, as negações aos estereótipos propostos para as mulheres na época servem, principalmente, de âncora para a afirmação que é posta na última estrofe (Eu sou infeliz!), mas aqui nessa afirmação talvez exista uma sutil ironia. $\mathrm{O}$ eu lírico constata que é infeliz depois de inúmeras negações aos padrões impostos ao sexo feminino. Nesse sentido, a infelicidade pode ser a de quem se sente deslocado socialmente e não necessariamente a de quem não encontrou o outro do seu afeto. Se, como afirma Muzart (1996), a mulher só era valorizada pelos atributos físicos, pela aparência e comportamento angelical, se sua fala deveria pautar-se em eufemismos, o eu lírico, ao perceber que não se encaixa nesses padrões, assume não ter "nada" para dar. Somente tem "o coração constante em te amar". O interessante nessa afirmação é que o eu lírico afirma não poder oferecer nada ao seu amor, além do coração, mas dedica-lhe um poema. Então, ao que nos parece nas fímbrias do discurso, o que se afirma é que o eu lírico não pode oferecer nada do que socialmente lhe é exigido, simplesmente porque não se enquadra nos requisitos impostos à mulher. $\mathrm{O}$ que pode oferecer são poemas que, escritos por uma mulher, eram vistos como menor e de pouca monta.

No poema abaixo intitulado Ângelus, de Francisca Júlia, veremos que, a partir da metáfora das aves, a autora sinaliza para os tormentos femininos no século XIX:

“Ângelus"

Desmaia a tarde. Além, pouco e pouco, no poente, O sol, rei fatigado, em seu leito adormece:

Uma ave canta, ao longe; o ar pesado estremece

Do ângelus ao soluço agoniado e plangente.

Salmos cheios de dor, impregnados de prece,

Sobem da terra ao céu numa ascensão ardente.

E enquanto o vento chora e o crepúsculo desce,

A ave-maria vai cantando, tristemente.

Nest'hora, muita vez fala a saudade

Pela boca da noite e pelo som que passa,

Lausperene de amor cuja mágoa me invade,

Quisera ser o som, ser a noite, ébria e douda

De trevas, o silêncio, esta nuvem que esvoaça,

Ou fundir-me na luz e desfazer-me toda.

(SILVA, 1961, p. 113-114).

Notemos que, ao falar "uma ave canta, ao longe; o ar pesado estremece", o eu lírico está sinalizando para a intolerância masculina para com a voz feminina. Além disso, esse cantar se dá justamente no final da tarde ("Desmaia a tarde"), um dos poucos momentos em que as mulheres-escritoras, trancafiando-se em seus quartos, ficavam sozinhas para criar suas poesias. Outro ponto interessante no discurso presente no poema acima é que o eu lírico, ao falar dos "ângelus", "salmos cheios de dor", "impregnados de preces", menciona a ave-maria. Ao que parece, está-se falando não de uma oração, mas, sim, de um ser, que, talvez, possa ser tomado metaforicamente como uma mulher que canta tristemente.

IPOTESI, JUIZ DE FORA, v.23, n.1, p. 98-112, jan./jun. 2019 
Atrelada às temáticas do desejo e do amor, aparece em muitos poemas escritos por mulheres a imagem do pássaro. Tais quais os pássaros, as mulheres tinham a capacidade de alçar voo, mas estavam aprisionadas nas gaiolas dos preconceitos impostos pela sociedade. Ainda se valendo da mesma metáfora, as mulheres eram pássaros que, sensuais, não podiam expor-se. Elas "podiam" cantar, mas talvez seu canto não fosse ouvido ou era esperado que não fosse ouvido para que a ordem do discurso social não sofresse abalo algum. Com frequência, a temática dos pássaros seria usada ainda para expor o desejo reprimido de algumas poetisas que, não falando abertamente o que sentiam, procuravam artifícios para expressarem-se e não sucumbirem aos próprios sentimentos, como assim anseia o eu lírico do poema de Francisca Júlia a partir de um desejo que aparece sutilmente no último verso do primeiro terceto e ganha corpo nos versos do segundo terceto.

Entre os escritos de autoria feminina de tempos de outrora, houve também um grande número de poemas que tratavam da infância e outros que exaltavam o amor pela nação "enaltecendo o pitoresco e o exótico, como formas de atrair a atenção no sentido de afirmar o conhecimento da terra. É necessário tomar posse dessa terra, possuí-la através da palavra" (PAIXÃO, 1991, p. 86). Uma das principais poetisas que se destacou com essa temática foi Narcisa Amália, que intentou afirmar sua identidade de poetisa evidenciando sua pátria. Há quem deixe claro, inclusive, que sua "produção poética [...] não fica aquém da de Gonçalves Dias, no que diz respeito à exaltação da natureza, nem da obra de Castro Alves", uma vez que "seus poemas de cunho social e político são igualmente intensos e críticos" (FAEDRIC, 2016, p. 07).

Com um grande rigor descritivo, a poetisa, como veremos a seguir, no poema dedicado e intitulado A Resende, apresenta e exalta suas “origens", em uma tentativa não só de evidenciar o amor por sua terra, mas também de ir ao mais profundo estado de sua alma; é nessa busca por equilíbrio e por paz que ela se autodescobre.

\author{
"A Resende" \\ Enfim te vejo, estrela da alvorada, \\ Perdida nas alagens do horizonte! \\ Enfim te vejo, vaporosa fada, \\ Dolente presa de um sonhar insonte! \\ Enfim, de meu peregrinar cansada, \\ Pouso em teu colo a suarente fronte, \\ E, contemplando as pétreas cordilheiras, \\ Ouço o rugir de tuas cachoeiras! \\ Mal sabes que profundos dissabores \\ Passei longe de ti, éden de encantos! \\ Quanto acerbo sofrer, quantos agrores \\ Umidecico'as bagas de meus prantos! \\ Sem um raio sequer de teus fulgores... \\ Sem ter a quem votar meus pobres cantos... \\ Ai! O simun cruel da atroz saudade \\ Matou-me a rubra flor da mocidade! [...] \\ (AMÁLIA, 2017, p. 15).
}

Mesmo a poetisa não tendo nascido em Resende, para onde foi apenas partir dos onze anos de idade, notemos que ela nutria por esta cidade grande amor como se fosse realmente sua terra de nascimento. A repetição do advérbio "enfim" no primeiro, terceiro e quinto versos evidencia o quão esperado era o reencontro do eu lírico com a cidade de seu afeto, após "peregrinar" por longos anos ("Enfim te vejo, estrela da alvorada,/ Enfim te vejo, vaporosa fada/ Enfim de meu peregrinar cansada). O interessante é que, ao apresentar, a partir de

IPOTESI, JUIZ DE FORA, v.23, n.1, p. 98-112, jan./jun. 2019 
justaposições, esta cidade como uma "estrela", "fada" e até "presa", se acentua o quão buscada era essa pátria que parece ser o guia do eu lírico. Ora, basta termos em mente que, desde os primórdios da civilização, em algumas situações, principalmente, se estamos perdidos, as estrelas, além de representarem luz, servem como forma de orientação, quase uma espécie de bússola. Inclusive se recorremos à religião, foi uma estrela o astro seguido por homens no dia do nascimento de Jesus Cristo. Já ao assemelhar a sua terra a uma fada, o eu lírico transfere o fator "maravilhoso" deste ser a sua pátria. No último quesito, ao deixar claro que sua pátria seria a presa, intensifica-se o quão a cidade era procurada. Então, ao que nos parece, ao assemelhar a sua "pátria" a esses "elementos", o eu lírico confere àquela terra também ditos aspectos. Dessa forma, Resende seria uma luz que guia o eu lírico, além de ser encantadoramente maravilhosa e, por isso, veementemente almejada.

Inclusive é nesta cidade que a autora mostra encontrar aconchego de mãe, da pátria mãe ("Pouso em teu colo a suarente fronte"). Por isso, tanto sofrimento e saudade por ficar longe, quando jovem de seu éden: "Mal sabes que profundos dissabores/ Passei longe de ti, (...)/ Quanto acerbo sofrer, quantos agrores/ Umidecico'as bagas de meus prantos/ Ai! O simun cruel da atroz saudade/ Matou-me a rubra flor da mocidade![...]". Na realidade, mais que uma porção de terra, Resende é exaltada como se fosse a musa inspiradora do eu lírico, por isso dedica-se o poema a ela. É o que podemos notar no verso como: "Sem ter a quem votar meus pobres cantos". Na realidade, o sentimento de pertença a uma cidade, região ou estado animava muitas escritoras a manejar a pena para escrever suas poesias. Em outras palavras, o "país de natureza pródiga, das matas e bosques" (BOSI, 2004, p. 127) era fonte de inspiração para muitas poetisas, que "ousaram" adentrar no meio literário.

Além dessas temáticas, outras tantas poetisas, a partir de um mergulho para dentro de si mesmas, falaram do inverno, do silêncio e da morte. De acordo com Paixão (1991), no caso dos poemas que falavam da morte, essa não era entendida como término de tudo, como fim do ser, mas, sim, como possibilidade para um recomeço, para uma purificação, se configurando assim como um estado transitório que poderia levar a alcançar a tão sonhada e desejada liberdade. Dentre as poetisas que escreveram sob tal perspectiva, destacamos o nome de Júlia Cortines, com a poesia intitulada $A$ um cadáver.

"A um Cadáver"

Eis-te, enfim, a dormir o teu sono de morte:

Semicerrado o olhar, as pupilas serenas,

$\mathrm{Na}$ atitude de quem nada teme da sorte,

Deslembrado do amor e esquecido das penas.

Nada pode turbar-te em teu repouso: estala

O raio, a lacerar das nuvens os vestidos;

No espaço a luz se extingue, o estampido se cala,

Sem vir ferir-te o olhar ou ferir-te os ouvidos.

Livre, afinal, da vida a que estava sujeito,

Teu calmo coração nenhum afeto encerra,

E, em pouco, como tu, ele estará desfeito

Sob o espesso lençol da camada de terra...

A afeição, que, fiel, te acompanhava, deve

Ficar, a pouco e pouco, à tua ausência alheia.

Passaste; e o esquecimento há de apagar, em breve,

O sinal que o teu passo imprimiu sobre a areia...

Que importa? Estás dormindo o teu sono de morte:

Semicerrado o olhar, as pupilas serenas,

IPOTESI, JUIZ DE FORA, v.23, n.1, p. 98-112, jan./jun. 2019 
$\mathrm{Na}$ atitude de quem nada teme da sorte, Deslembrado do amor e esquecido das penas.

(CORTINES, 2010, p. 152)

O século XIX foi marcado por diversas transformações sociais, políticas e econômicas, no Brasil, dentre elas podemos elencar a Proclamação da República e a Abolição da Escravatura que sinalizavam para tempos promissores. Porém, mesmo com essas boas investidas, a literatura brasileira, sofrendo influência da estética decadentista vindas de países como França e Portugal, permeou-se do espírito pessimista que levou à aspiração à morte. "A literatura feminina, no Brasil, aponta agora para a liberdade trágica das mulheres - a liberdade na Morte" (PAIXÃO, 1991, p. 100). Ou seja, as mulheres escritoras viram na morte uma saída para seus problemas. Como afirma Affonso Romano de Sant'Anna: “a morte é sempre uma hipótese de libertação em relação ao corpo, uma superação dos mistérios. Mais do que isto, a morte bem pode ser o cessar de todo sofrimento" (SANT'ANNA, 1984, p. 07 apud PAIXÃO, 1991, p. 110). É o que podemos constatar na poesia acima.

Observemos que o discurso presente neste escrito, mais que revelar o olhar de uma mulher para a passagem da vida alheia, deixa clara a exaltação de Cortines à morte. Notemos que, enquanto o advérbio de tempo "enfim" logo no primeiro verso sinaliza para o quão esperada era a morte, o também advérbio de tempo "afinal", no nono verso, aponta para a alegria e alívio do eu lírico com a ida da vida. No estado de desânimo, o eu lírico, cansado do fardo que tão pesado carregava e "na atitude de quem nada teme da sorte, / Deslembrado do amor e esquecido das penas", vê a morte como um repouso, onde "a luz se extingue, e o estampido se cala,/ Sem vir feri-te o olhar ou ferir-te os ouvidos".

Observemos também que o eu lírico tem plena consciência do quão efêmera é a vida e de que, após a morte de uma pessoa, os feitos dela podem cair no esquecimento: "Passaste; e o esquecimento há de apagar, em breve,/ O sinal que o teu passo imprimiu sobre a areia..."; quanto a isso, notemos que o eu lírico afirma não se importar com esse esquecimento, ao contrário, com o verso "Que importa?", implicitamente deixa a cargo do leitor avaliar a importância que pode ser dada a algo ou alguém após a morte.

Outro ponto interessante é que, ao iniciar o poema, o verso ("Eis-te, enfim, a dormir o teu sono de morte:") indica que a pessoa de quem se fala está ainda viva, e já no término o verso ("Estás dormindo o teu sono de morte:") aponta que o moribundo faleceu; ou seja, ao que parece a pessoa enquanto a poetisa escrevia estava viva e quando ela cessou a ação não resistiu, ou ainda, esse ser conseguiria um "sopro" de vida todas as vezes que alguém lesse essa poesia. Ao que nos parece, Cortines correlacionou escrita, leitura e vida. Além disso, as descrições do moribundo, quando vivo e quando morto, são iguais e bem sugestivas: "Semicerrado o olhar, as pupilas serenas," (segundo e décimo oitavo versos). Ou seja, há certa vigilância mesmo após a morte, o que nos remete a certa vontade de viver. O que nos parece é que a autora não nutria horror pela vida em si, mas, sim, pela vida a que as mulheres oitocentistas estavam submetidas. Dito de outra forma, a nosso ver, nas fimbrias desse discurso que enaltece a morte como forma de libertação, está a aspiração de Cortines por uma vida diferente e melhor do que a que era imposta ao sexo feminino no oitocentos.

$\mathrm{Na}$ realidade, a partir de suas poesias, as mulheres-escritoras do entresséculo (XIX/XX) vão "além das suas próprias questões emancipatórias e apresentam uma linha ideológica mais definida e aguerrida" (SIQUEIRA; DANTAS, 1991, p. 137). Nesse sentido, se nos detivermos a analisar "a produção literária de autoria feminina desse período, veremos que as mulheres tiveram, de várias maneiras, uma atuação política, se entendemos como tal a atuação em movimentos e sociedades" (MUZART, 1996, p. 151) a favor da libertação dos escravos, da institucionalização da educação feminina e do direito ao voto. Isso se torna possível porque "a ideologia estaria difusa na obra de arte", uma vez que o sexo feminino, não podendo subtrair- 
se "aos discursos de classe ou de grupo social que pretendem explicar o funcionamento da sociedade, os seus valores ou, mais ambiciosamente, o sentido da vida", (BOSI, 1995, p. 02) expunha suas próprias percepções através de suas poesias. Foi dessa forma que algumas poetisas "desfraldaram sua bandeira de combate ao governo, e contra o sistema, contra os políticos retrógrados que mantinham interesse na preservação do sistema social fundado na escravidão" (SIQUEIRA; DANTAS, 1991, p. 137). Entre essas poetisas, "que escreveram com conotação política, que puseram a pena a serviço da ideologia” (MUZART, 1995, p. 155), podemos citar o nome de Maria Amélia Queiroz, autora do poema intitulado, não por acaso, $A$ Deusa Liberdade.

\author{
"A Deusa Liberdade" \\ Construam templos suntuosos, belos \\ A' causa santa, que soluça - Deus, \\ Onde a harmonia foi achar seu trono, \\ Na esfera lúcida, o alcantil do céu \\ E a casta deusa, de semblante altivo \\ Num doce enlevo, quer voar além... \\ E a terra dorme num letargo plácido \\ Quando as estrelas deslumbrantes vêm. \\ Do mar no centro, se deslizam pérolas \\ De imenso brilho e de celeste alvor, \\ Para exortar aquelas frontes cândidas \\ Onde se gravam liberdade e amor \\ Tudo se alegra neste dia santo \\ A meiga aurora com prazer raiou \\ E a natureza se cobriu de flores \\ Para saudá-la - nova luz- criou \\ Ouve-se um hino que arrebata a alma, \\ Entre doçuras de harmonia cética, \\ O céu... a terra, se contemplam estáticos \\ Admirando essa beleza angélica \\ E Deus, ouvindo esses etéreos cânticos \\ Cheios de preces pela humanidade \\ Diz: "caminhai" e a multidão celeste \\ Conduz o anjo, que diz... Liberdade.
} (QUEIROZ, 1885, p. 05, apud SIQUEIRA; DANTAS, 1991, p. 137)

Não há dúvidas de que a partir de suas poesias as mulheres-escritoras se fizeram resistentes aos paradigmas vigentes na sociedade que intentavam confiná-las na esfera doméstica (SILVA, 2012), como escravas que ainda não tinham recebido sua alforria. "Mais do que ninguém, as mulheres entendiam de opressão; mais do que ninguém, conheciam o valor da palavra LIBERDADE" (SIQUEIRA; DANTAS, 1991, p. 137).

No poema acima, notemos que a liberdade é personificada e vista como uma verdadeira deusa. Por isso, logo na primeira estrofe, que serve de ancora para o que será exposto ao longo de todo o escrito, observemos que para a divindade - a Liberdade - o eu lírico diz ser necessário construir templos na terra, local onde deveria haver a supremacia de tal deusa. Ou seja, os "templos suntuosos, belos" devem ser construídos onde, embora ainda não haja a morada da Liberdade, há pessoas que sentem ânsia por ela. Percebamos que esse desejo de liberdade é 
cravado no quarto verso da primeira estrofe, quando aparece o "céu", que já sinaliza para certa elevação sobre as coisas terrenas. Essa elevação é ainda mais enfatizada na segunda estrofe, na qual percebemos que "a casta deusa, de semblante altivo/ Num doce enlevo, quer voar além". Desses versos podemos perceber dois pontos de suma importância. Primeiro, esse ser não se mostra passivo, ao contrário, há no seu rosto certo brio e impavidez, o que leva o/a leitor/a a pensar que essa deusa não se inclina facilmente mesmo diante das mais ásperas situações. Segundo, é justamente enquanto "a terra dorme" e "as estrelas deslumbrantes vêm", que a deusa deseja alçar voo. Ou seja, enquanto algumas almas descansam, outras sentem aflorar o sentimento e a vontade de livrar-se de toda e qualquer amarra que impeça o seu voo de liberdade.

Ora, notemos que nessa ode à liberdade, ao estilo romântico, a autora transgride os limites impostos à dicção feminina e expressa sua inconformidade com a situação de aprisionamento a que as mulheres oitocentistas estavam submetidas. Na realidade, como afirmam Sayre e Löwy (1996, p. 10), "algumas escritoras estavam ao mesmo tempo preocupadas com a emancipação das mulheres e atraídas pelo romantismo". Percebamos também que, para além da liberdade feminina, a autora do poema acima, sofrendo a influência dos ideais românticos, canta e exalta o desejo de que todos os seres humanos, independentemente de seu sexo, sejam livres. Em outras palavras:

\footnotetext{
Ela se recusa a aceitar limites e se entrega a sonhos infinitos sobre coisas que poderiam e deveriam acontecer, uma atividade que Bloch denomina "orientada para o futuro": sonhar "para a frente" (nachVarwarts). É nesse sentido que sua sensibilidade romântica apresenta influência política. Ela é uma reprovação viva à sociedade por encarnar a luta pela liberação humana, e ao mesmo tempo mostrar ser difícil viver nessa sociedade como realmente é (SAYRE, LÖWY, 1996, p. 15).
}

Sem dúvida, imersa em uma sociedade calcada em princípios patriarcais e elitistas, a poetisa encontra na escrita de poemas uma forma de expressar-se que se coaduna com a busca por libertação. Mais que isso, através do poema acima, a escritora intenta tocar os indivíduos que também almejam a liberdade. Isso fica explícito quando, na terceira estrofe, o eu lírico não mais se dirige estritamente para a deusa, mas, sim, para "aquelas" pessoas de "frontes cândidas onde se gravam liberdade e amor". Dessa maneira, o poema deixa de pretender exaltar apenas um ser e passa a enaltecer todos/as que, de alguma forma revolucionando e transpondo os preceitos de então, compartilham dos mesmos ideais que a divindade fomenta. Em outros termos, "a poesia se concretiza no momento em que as ideias e os sentimentos de um grupo tomam a forma de composições, arranjos intencionais" (BOSI, 2001, p. 96), moldados pela pena da escritora que, ao cantar a liberdade, se coloca como porta voz de um povo. É para essas pessoas que "do mar no centro, se deslizam pérolas".

O curioso é que, corroborando os princípios românticos, a natureza, ao que nos parece, não serve apenas como mero elemento figurativo dentro do poema, mas tem uma participação dinâmica. Ela é também a expressão do culto à deusa Liberdade. Isso fica nítido na quarta estrofe, nos versos como: "tudo se alegra neste dia santo/ A meiga aurora com prazer raiou/ E a natureza se cobriu de flores/ Para saudá-la - nova luz - criou". Ora, percebamos que a natureza se prepara para receber o ser divino. Mais que isso, a natureza parece se confundir com as pessoas que têm a Liberdade por deusa. Ou ao menos, "a representação da natureza expressando estados de espírito serve como libertação" (BARROS, 2014, p. 20) das amarras sociais.

Outro ponto interessante é que, ao longo do poema, percebemos que a Liberdade, mais que deusa, é a musa inspiradora do eu lírico para a qual se pretende oferecer tais versos. Por isso, na quinta estrofe, afirma-se que "ouve-se um hino que arrebata a alma". Com isso, levase o/a leitor a pensar que esse hino de "doçuras de harmonia cética" seria o próprio poema que homenageia a divindade enquanto "o céu... a terra se contemplam estáticos/ Admirando essa

IPOTESI, JUIZ DE FORA, v.23, n.1, p. 98-112, jan./jun. 2019 
beleza angélica". Notemos também que, no início do poema, céu e terra eram apresentados como polos distantes, inclusive não se mencionavam os dois na mesma estrofe, o que acentua ainda mais que eles estão em pontos extremos, porém, na quinta estrofe, se enfatiza que ambos ficam paralisados vendo a beleza da deusa. Em outros termos, agora tanto o céu como a terra são personificados, já que ambos "se contemplam estáticos, admirando essa beleza angélica" da deusa que parece ser o limiar entre esses dois "lugares".

Já na sexta e última estrofe, observemos que, a partir do que seria um pedido de Deus ("E Deus.../ Diz: 'caminhai"”), se enfatiza que a "humanidade", "a multidão celeste" deve continuar caminhando em prol da Liberdade. Assim "essa conotação de Liberdade, como deusa, como divindade, de certa forma se mostrava distante, etérea, mas também como algo sublime, puro, elevado, que deveria ser cultivado" (SIQUEIRA; DANTAS, 1991, p. 138). É justamente esse culto que é decantado ao longo de todo o poema pelo eu lírico. A liberdade deve ser o ideal a guiar a nação e os cidadãos, ainda que desse ideal tivessem ficado de fora muitas mulheres, uma vez que, não custa lembrarmos, os ideais da tríade Liberdade, Igualdade e Fraternidade, que embasaram os princípios da Revolução Francesa, não se aplicaram a todos os indivíduos (NEJAR, 2011). Tendo isto em mente, um poema dedicado à liberdade e escrito por uma mulher, ao que nos parece, sub-repticiamente, está passando a ideia de que a liberdade deveria ser essa deusa que, sob suas asas, acolheria a todos, independentemente do sexo a que os sujeitos pertencessem.

Para finalizar, podemos dizer que a poesia de autoria feminina no Brasil oitocentista não se restringiu a poemas sentimentais. Em meio às queixas da alma, imiscuía-se um sentimento de revolta contra a opressão sofrida pelas mulheres e pelos menos favorecidos, sentimento esse que também apontava para o desejo de participação das mulheres no destino político do país ou no espaço público onde decisões políticas eram tomadas. Estudando a produção das mulheresescritoras do entresséculo (XIX/XX), consideradas predecessores, Muzart (1996) desconstrói a concepção, ainda hoje em voga, de que essa literatura seria uma literatura "choramingas", piegas, sem muito requinte. $\mathrm{O}$ que a referida pesquisadora vai afirmar, assim como outros/as estudiosos/as, é que as mulheres-escritoras se utilizaram da escrita de poesias para obterem voz cujos sons passaram a ecoar do âmbito privado para o espaço público.

Não obstante, as mulheres-escritoras oitocentistas, mostrando-se em dia com as questões partidárias concernentes ao século XIX, também utilizaram da escrita de poemas para apoiar ou rechaçar os grupos políticos que estavam aparecendo na época. Foi justamente isso que aconteceu "quando as ideias de independência - de república e de federalismo - estiveram presentes nos projetos políticos que contrariavam o poder absolutista que D. João VI [então imperador], estava implantando no Brasil" (MUZART, 1996, p. 151), momento em que as mulheres-escritoras engajaram-se nesses movimentos e transcreveram para o papel suas próprias inquietações. Por tudo isso, "aquela imagem cristalizada pelo cinema e pela literatura das sinhazinhas a se embalarem indolentes nas redes, atendidas pelas mucamas" (MUZART, 1996, p. 159) não dá conta de representar o que realmente foi a mulher-escritora e sua participação na sociedade oitocentista. De acordo com Muzart (1996, p.152), "pode-se, lendo a produção inicial dessas mulheres, constatar que sempre houve um 'pendant' político na sua lavra".

No que concerne especificamente às poesias aqui analisadas, podemos perceber que elas se inserem dentro da tradição literária brasileira do entresséculo (XIX/XX), uma vez que dialogam com as estéticas literárias vigentes na época, entre elas o Simbolismo, Parnasianismo e Romantismo. É justamente a partir de tais tendências que as poetisas, apresentadas ao longo deste artigo, empreendem um duplo movimento: ora dialogam com os códigos estéticos finisseculares, ora os rejeitam e os ultrapassam buscando uma "liberação dos moldes e [...] dos valores impostos" (MUZART, 1990, p. 20). Justamente por isso, como uma espécie de punição por ir de encontro ao que estava posto na sociedade e escrever, quando a escrita era considerada

IPOTESI, JUIZ DE FORA, v.23, n.1, p. 98-112, jan./jun. 2019 
um ofício masculino, muitas poetisas foram relegadas ao esquecimento. Nesse caso, uma escritora esquecida ou não lida "é vítima de um tipo particular de censura, o da indiferença, que é uma censura efetiva e eficaz". Isso porque "uma cultura se define tanto por suas atitudes e seus projetos futuros quanto por suas recordações e paisagens do passado" (TELLES, 1989 citado em GONÇALVES, 2015, p. 41). Por isso, há algumas décadas, estudiosos e estudiosas das universidades brasileiras vêm empreendendo estudos e esforços para que a nossa historiografia literária seja estudada a partir de suas margens e não somente de seu centro.

\title{
Voicesofyesteryear: poetrybywomenwriters in late $19^{\text {th }}$ centuryandearly $20^{\text {th }}$ centuryBrazil
}

\begin{abstract}
This article pertains to the academic realm of the recovery and recognition of Brazilian thought and cultural endowment. It is based on the analysis of poems by $19^{\text {th }}$ century women writers, examining how these women, in particular Gilka Machado, Pórcia C. Melo, Francisca Júlia, Narcisa Amália, Júlia Cortines and Maria Amélia Queiroz, dialogue with or collide against the $19^{\text {th }}$ century Brazilian literary aesthetic.
\end{abstract}

Keywords: 19th century Brazilian poetry. Women's writing. Feminist criticism.

\section{NOTAS}

${ }^{1}$ Nascida em 1893, no Rio de Janeiro, Gilka Machado começou a fazer poesias ainda criança, ganhando aos 13 anos um concurso promovido pelo jornal A imprensa. Casou-se em 1910, com o poeta, jornalista e crítico de arte Rodolfo Machado (com quem teve dois filhos), e aos 22 anos, em 1915, publicou seu primeiro livro Cristais Partidos. Em seguida, vieram as publicações de Estados d'Alma (1917), Mulher Nua (1922), Meu Glorioso Pecado (1928), Amores que mentiram, que passaram (1928). Tendo por temática central de suas obras o desejo feminino sobre o qual, pioneiramente, falou em nossas letras, Gilka Machado "ousou" falar sobre sensações, imaginações e sonhos, considerados impróprios à dicção feminina, e a crítica logo se pronunciou, na maioria dos casos, difamando-a. O que boa parte dos críticos não aceitava, porque não estava acostumada, era que uma mulher mostrasse talento independente dos preceitos estabelecidos na época. A poetisa ficou conhecida também fora do Brasil ao ter suas poesias traduzidas para o espanhol. Quanto à tendência seguida por ela, há controvérsia, enquanto alguns estudiosos consideram-na simbolista, outros a veem como parnasiana. A poetisa recebeu, em 1979, da Academia Brasileira de Letras, o prêmio Machado de Assis, pela publicação de Poesias Completas. E atualmente é considerada "marco de liberação da mulher" (SOARES, 1999, p. 05 apud DIAS, 2011, p. 03).

${ }^{2}$ Jornalista e poetisa pernambucana, Pórcia Constância de Melo dirigiu de 1890 a 1899 o "periódico crítico e científico" (SIQUEIRA; DANTAS, 1991, p. 136), A Rosa, onde publicou a poesia Que me Pedes. Como bem evidenciam Siqueira e Dantas (1991), ao mapearem os temas abordados pelas poetisas no Recife no século XIX, as mulheres se valeram de jornais com o nome de flores, para, a partir da imagem de fragilidade que o nome conotava, assumir aos poucos a palavra. Assim, Pórcia estrategicamente fala "das flores e dos espinhos, uma antítese que evidencia sua existência de contrastes e lutas" (SIQUEIRA; DANTAS, 1991, p.140). A poetisa foi também proprietária da tipografia conhecida como D. Pórcia, onde imprimiu consideráveis números da revista $A$ República, do Centro Republicano de Pernambuco (1888), e O Larousse, órgão do Partido Católico e da Sociedade de Homens de Letras (1890).

${ }^{3}$ Poetisa e professora, Francisca Júlia da Silva, nasceu em 31 de agosto de 1871. Em 1895 publicou, pela editora Horácio Belfort Sabino, seu primeiro livro, Mármores, com o qual adquiriu popularidade. Posteriormente, veio a publicação do Livro da Infância (1899), contendo pequenos contos e versos; de Esfinges (primeira edição publicada em 1093 e segunda edição em 1921) que foi uma ampliação de Mármores; de A feitiçaria sob o ponto de vista cientifico (1908), um discurso; de Alma infantil (1912), obra elaborada em parceria com seu irmão Júlio César da Silva, de cuja edição foi adquirida parte considerável pelo então secretário do Interior, Altino Arantes, para ser usada nas escolas estaduais; e de Poesias (1962), obra organizada por Péricles Eugenio da Silva Ramos. Sendo considerada uma das mais importantes poetisas da época, Francisca Júlia foi proclamada, em 1904, membro efetivo do comitê Central Brasileiro da Societá Internazionable Elleno-Lalina, de Roma. E em 1909 casou-se com Filadelfo Edmundo Munster, que veio a falecer em 31 de outubro de 1920. Um dia após a morte do marido, Francisca Júlia suicidou-se após ingerir alta dose de narcóticos.

${ }^{4}$ Poeta, professora e primeira brasileira a se profissionalizar em jornalismo, Narcisa Amália de Campos nasceu em 03 de abril de 1852 em São João da Barra, Norte do Rio de Janeiro. Com 11 anos, mudou-se com os pais para Resende, cidade em que viria a casar-se, aos 14 anos, com o artista ambulante João Batista da Silveira, de quem se separaria após poucos anos. Com 20 anos, em 1872, a poetisa publicou o livro Nebulosas, prefaciado pelo

IPOTESI, JUIZ DE FORA, v.23, n.1, p. 98-112, jan./jun. 2019 
intelectual, renomado escritor e jornalista Pessanha Póvoa. Neste livro, onde a autora dialoga com o Romantismo, "constam poemas ecléticos: líricos, de teor intimista, laudatórios comemorativos, dirigidos à natureza, e poemas de cunho social” (FAEDRICH, 2016, p.07). Em 1880, aos 28 anos, casa-se novamente, desta vez, com o padeiro Francisco Cleto. Mesmo o ajudando na padaria, Narcisa continuou a fazer suas poesias, não se afastando das esferas literárias, inclusive o imperador Dom Pedro II, em visita a Resende, reconhecendo o talento da autora, foi visitá-la e elogiou-a pessoalmente. Poucos anos depois, a poetisa separa-se de Cleto e muda-se para o Rio de Janeiro, onde se dedicou ao magistério e fundou, em 13 de outubro de 1884, o jornal quinzenal O Gazetinha. Além de escrever poemas, Narcisa Amália traduziu contos e ensaios de alguns autores franceses, como História de minha vida, de George Sand, Romance de uma mulher que amou, de Arséne Houssave, e Os climas antigos, de Gaston de Saporta.

${ }^{5}$ Filha de Júlia Mesquita Cortines Laxe e do então jornalista e deputado federal João Batista Cortines Laxe, Maria Júlia Cortines Laxe nasceu em 12 de dezembro de 1868 em Rio Bonito, Rio de Janeiro. Desde cedo, imersa no mundo das letras, mostrou grande interesse pela literatura, escrevendo poemas aos 13 anos de idade. Aos 21 anos, indo de encontro ao que lhe era imposto, começou a publicar seus poemas em periódicos da corte. De acordo com Paixão (1991), a poetisa escreveu, ao viajar pela Europa, para o jornal “O país” em uma coluna chamada “Através da vida". Aprofundando seus estudos em literatura, passou a ministrar aulas tendo em sala nomes renomados como Lúcio Costa e Haroldo Valadão. Júlia Cortines, seguindo as tendências do Simbolismo e do Parnasianismo, ficou conhecida principalmente por seus únicos dois livros. O primeiro intitulado de Versos data de 1894 e foi publicado pela Leuzinger. O segundo livro intitulado Vibrações foi publicado em 1905 pela Laemmert \& C., que, de acordo com Araújo (1899 apud CORTINES, 2010), era uma das maiores editoras de então.

${ }^{6}$ Jornalista, abolicionista e poetisa, Maria Amélia de Queiroz nasceu em Pernambuco no século XIX. Tendo uma educação privilegiada, a escritora, culta e inteligente, se reunia às escondidas com os/as componentes do chamado Clube do Cupim, uma associação de cunho abolicionista que, se mantendo secreta, era comandada por José Mariano e tinha por demais participantes Joaquim Nabuco, Barros Sobrinho, Alfredo Pinto e João Ramos. Em 20 de abril de 1884, ajudou a fundar a associação Ave Libertas, a qual integrava um grupo de mulheres que, em um intento de diminuir o sofrimento de dezenas de seres humanos, arrecadavam fundos para libertá-los da escravidão. Os encontros aconteciam em Poço da Panela, onde séculos antes tinha lugar o Engenho da Casa Forte. Em 1885, a associação Ave Libertas fundou o jornal com o mesmo nome e com os mesmos objetivos da associação. Um ano após, em 1886, seria fundado o periódico Vinte e Cinco de Março, que, mesclando publicações (entre elas poemas) femininas e masculinas, incentivava as famílias a juntarem-se à causa abolicionista. Maria Amélia de Queiroz lutou também pela causa feminista e colaborou no jornal A família, de Josefina Álvarez de Azevedo.

\section{Referências}

AMÁLIA, Narcisa. Nebulosas. Apresentação e posfácio de Anna Faedrich. 2. ed. Rio de Janeiro: Gradiva, Fundação Biblioteca Nacional, 2017.

BARROS, Sílvia. Autoria feminina: romantismo na contemporaneidade. Revista Terra Roxa e outras terras, Rio de Janeiro, v. 27, jun./dez. 2014. Disponível em: http://www.uel.br/pos/letras/terraroxa/g_pdf/vol27/TR27b.pdf. Acesso em: 02 maio 2019.

BOSI, Alfredo. História concisa da literatura brasileira. 38. ed. São Paulo: Cultrix, 2001.

Formações ideológicas na cultura brasileira. Estudos Avançados, São Paulo, 1995. Disponível em: http://www.scielo.br/scielo.php?script=sci_arttext\&pid=s01340141995000300021. Acesso em: 03 fev. 2019.

BOSI, Viviana (org.). O poema: leitores e leituras. 2 ed. Cotia: Ateliê, 2004.

CORTINES, Júlia. Versos - Vibrações. Rio de Janeiro: Academia Brasileira de Letras, 2010.

DIAS, Júlio Cesar Tavares. Erotismo de Gilka Machado: marco da liberação da mulher na literatura. Campinas: Unicamp, 2013. Disponível em:

IPOTESI, JUIZ DE FORA, v.23, n.1, p. 98-112, jan./jun. 2019 
http://www.unicap.br/coloquiodehistoria/wp-content/uploads/2013/.../5col-p.369-382.pdf. Acesso em: 01 set. 2016.

FAEDRICH, Anna. Narcisa Amália e as intempéries da produção literária feminina. Palimpsesto, Rio de Janeiro, v. 15, n. 22, jan./jun, 2016. Disponível em:

http://www.pgletras.uerj.br/palimpsesto/num22dossie09.pdf. Acesso em: 14 set. 2016.

FERREIRA, Luzilá Gonçalves. Em busca de Thárgelia: a poesia escrita por mulheres em Pernambuco no Segundo Oitocentismo (1870-1920). Tomo I. Recife: FUNDARPE.

FRANCISCA JÚLIA. Poesias. Organização de Péricles Eugênio da Silva Ramos. São Paulo: Imprensa Oficial do Estado de São Paulo, 1961.

GONÇALVES, Francisco de Souza. $A$ “autor $+a$ ” segundo Norma Telles: pensando a literatura produzida por mulheres no entresséculo XIX-XX. Revista XIX: artes e técnicas em transformação, n. 2, 2015. Disponível em:

http://www.periodicos.unb.br/index.php/recistaXIX/article/view/16583. Acesso em: 15 out. 2018.

MACHADO, Gilka. Poesia completa. São Paulo: Selo Demônio Negro, 2017.

MUZART, Zahidé Lupinacci. Artimanhas nas entrelinhas: leitura do paratexto de escritoras do século XIX. ANPOLL, Recife, 1990. Disponível em:

https://periodicos.ufsc.br/index.php/travessia/article/download/17202/15776. Acesso em: 10 ago. 2018.

Mulheres de faca na bota: escritoras e política no século XIX. Seminário Mulher e literatura, Recife. In: Anais... Rio de Janeiro, 1996. Disponível em: https://periodicos.ufsc.br/index.php/literatura/article/download/5284/4714. Acesso em: 10 ago. 2018

NEJAR, Carlos. História da literatura brasileira: da carta de Caminha aos contemporâneos. São Paulo: Leya, 2011.

PAIXÃO, Sylvia. A repressão do desejo na poesia feminina: a fala-a-menos. Rio de Janeiro: Numen, 1991.

PEREIRA, Cláudia Gomes Dias Costa. Contestado fruto: a poesia esquecida de Beatriz Brandão. 2009. 524 f. Tese (Doutorado em Letras) - Programa de Pós-Graduação em Letras, Universidade Federal de Minas Gerais, Belo Horizonte, 2009.

SAYRE, Rober; LÖWY, Michael. Romantismo como visão feminista: a busca de Christ Wolf. Revista Transformação, São Paulo, v. 19, 1996. Disponível em: www.scielo.br/pdf/trans/v19/v19a01.pdf. Acesso em: 02 maio 2019.

SILVA, Marcelo Medeiros da. Poesia e resistência no Brasil: o caso das poetisas oitocentistas. Revista Ártemis, v. 14, ago./dez. 2012. Disponível em: http://periodicos.ufpb.br/index.php/artemis/article/viewFile/143110/8185. Acesso em: 15 ago. 2018.

IPOTESI, JUIZ DE FORA, v.23, n.1, p. 98-112, jan./jun. 2019 
SIQUEIRA, Elizabeth Angélica Santos; DANTAS, Marluce Oliveira Raposo. A temática dos poemas femininos no Recife no século XIX: algumas constantes. Revista Travessia: Mulheres - Século XIX, set. 1991.

Data de submissão: 26/05/2019.

Data de aceite: $28 / 08 / 2019$. 